\title{
Customer Satisfaction on Bio-Farm Biodegrading Agent: A Study on Agricultural Product Customers
}

\author{
Indah Prihartini \\ University of Muhammadiyah Malang \\ indahprihartini@gmail.com
}

\author{
Sutawi \\ University of Muhammadiyah \\ Malang
}

\author{
Luqyana Salsabila \\ University of Muhammadiyah \\ Malang
}

\begin{abstract}
Competition among businesses in agricultural sectors keeps growing along the time; needs and interests of customers are the key determiners of designing and improving products. This current research aimed at investigating customer satisfaction level on bio-farm product particularly among agricultural product customers. The locations of this research were in Malang Regency, Malang City, and Batu City. Importance Performance Analysis (IPA) and Customer Satisfaction Index (CSI) were employed to analyze the data. It has been revealed that the customer satisfaction has been shown to be $73.88 \%$. The correlation between importance and customers' satisfaction has shown that the price and packaging are of low priority; whereas, the product's benefit, information, and content are salient for customers. Those three potential aspects are to be retained by businessmen and companies.
\end{abstract}

Keywords: customer satisfaction, bio-farm product, agriculture

\section{INTRODUCTION}

The growth of business areas has been colored by various modes of competitions, penetrating any aspects of which. There has been a very tight competition affecting the alteration of customer behaviors particularly in taking decision to purchase products. The vast and dynamic growing technology has demanded people to be tactical and precise in taking an action to keep pace with others and lose in any ceaseless competitions. Similar scenario applies to agricultural sector, in which farmers are required to perform their critical thinking as well as keep on innovating to compete and to be well-improved. Farmers, in this sense, are the most potential customers for agricultural products.

Bio-farm constitutes biodegrading agent. It contains lignochloritik bacteria equipped with high ability to degrade synthetic and organic wastes into highly potential organic material. Bio-farm possesses the following specifications: clear liquid, high fermentation activity, and odorless. It has been composed from: mixed minerals (N, P, K, Mg, and Fe), straw extract, ligninolytic, cellulosic, metagenomic, and pectinovora bacteria.

There are a number of agricultural products with varying specifications and qualities. All producers are highly assured about their products. The needs and interests of customers are key determiners to consider so as the products can be accepted by market. The fulfillment of those two-mentioned aspects affects the growth of businesses and companies. It is pivotal that all businessmen make use of those information when determining, running, as well as controlling their proper marketing strategies (Nitisusastro, 2011).

By means of an awareness of their customers' needs and interests, it is of urgency that businessmen monitor the ever-changing market growth. Accordingly, it is important that they meticulously study their customers as well as their behaviors (Nitisusastro, 2011). This current research aimed at investigating the level of customer satisfaction on bio-farm product (products' benefit, packaging, price, information, and content), particularly among agricultural product customers.

\section{METHOD}

\section{Method and Location}

The research respondents were recruited by employing purposive sampling technique, specifically the loyal customers (the selling partners) of the bio-farm product. This current research was conducted in several locations across Malang Regency, Malang City, and Batu City. The respondents were those who bought the product or prospective customers who had obtained information regarding the product from the partner stores.

\section{Data Collecting Technique}

The data were in the forms of primary and secondary data. The primary data were collected from structured interviews. The secondary data were collected from 
literatures relevant to this research and from some key institutions.

\section{Data Analysis}

Importance Performance Analysis was employed to analyze the data. It was done by following the stages as below (Supranto, 2001).

The level of compatibility (TKi) is calculated from performance and expectation levels:

$$
\text { Tki=Xi/Yi x 100\% }
$$

where:

$\mathrm{Tki}=$ respondents' compatibility level

$\mathrm{Xi}=$ score of performance

$\mathrm{Yi}=$ score of expectation

Below is the calculation for the average between performance $\mathrm{X}$ and expectation $\mathrm{Y}$ for all customers:

$\mathrm{X}=\Sigma \mathrm{Xi} / \mathrm{n}, \mathrm{Y}=\Sigma \mathrm{Yi} / \mathrm{n}$

where:

$\mathrm{X}=$ score for performance level

$\mathrm{Y}=$ score for expectation level

$\Sigma \mathrm{Xi}=$ total score for performance level

$\Sigma \mathrm{Yi}=$ total score for expectation level

$\mathrm{n}=$ number of respondents

Below is the calculation of the average between performance $\mathrm{X}$ and expectation $\mathrm{Y}$ for all attributes,

$$
\overline{\mathrm{X}}=\frac{\sum_{\mathrm{i}=1}^{\mathrm{N}} \overline{\mathrm{Xi}}}{\mathrm{K}} \quad \overline{\mathrm{Y}}=\frac{\sum \stackrel{\mathrm{N}}{\mathrm{i}=1 \overline{\mathrm{Yi}}}}{\mathrm{K}}
$$

where:

$\mathrm{K}=$ attributes affecting customer satisfaction

Below is the description of each attribute in Cartesian diagram, divided into four quadrants and limited by X, Y.

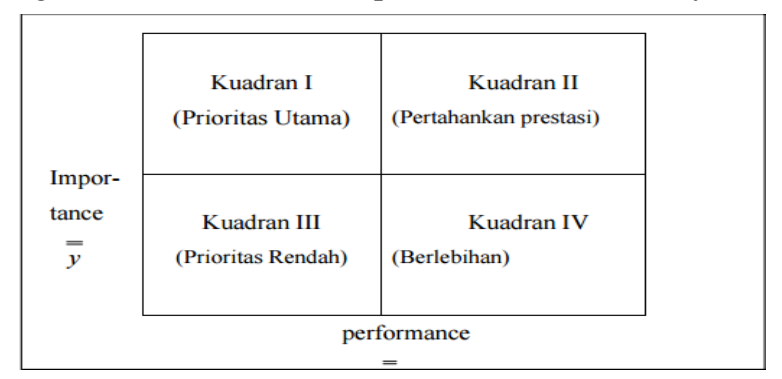

Figure 1. Quadrants in Importance-Performance Analysis (Source: Rangkuti, 2003)

The above Importance Performance Analysis (IPA)Diagram (Figure 1) comprises four quadrants:

Quadrant I, an area comprising items with relatively high importance level but has not met the users' expectations. The items belong to this quadrant require immediate performance improvement.

Quadrant II, an area comprising items with relatively high importance level with relatively high satisfaction level. The items belong to this quadrant are considered as satisfaction factors to maintain due to their potentials perceived by the users.

Quadrant III, an area comprising items with relatively low importance level with relatively low performance and satisfaction levels. The items belong to this quadrant contribute insignificantly towards the users' satisfaction on the product's benefit.

Quadrant IV, an area comprising items with relatively low importance level, perceived by the users as excessive, with relatively low satisfaction level. The expense used to support the items belonging to this quadrant is to be lowered so as to minimize cost (Rangkuti, 2003).

Customer Satisfaction Index

Customer Satisfaction Index is necessary to find out the holistic satisfaction level of the respondents by considering the importance level of product's or service's attributes.

Holistically, the satisfaction level of the respondents is seen from the criteria of satisfaction level of the respondents. The highest satisfaction level is achieved if CSI shows $100 \%$. Satisfaction ranges from 1-100\%. In this current research, the scale range of performance assessment is as follow:

$$
\mathrm{RS}=\frac{100 \%-0 \%}{5}=20 \%
$$

The scale range shows the responses of the customers to the stratified options, starting from low to high priority. The scale comprises: very dissatisfied, dissatisfied, fairly satisfied, satisfied, and very satisfied(Supranto, 1997). Based on the above scale range, the following is the satisfaction scale of the respondents:

$$
\begin{aligned}
& 0 \%<\mathrm{CSI} \leq 20 \%=\text { very dissatisfied } \\
& 20 \%<\mathrm{CSI} \leq 40 \%=\text { dissatisfied } \\
& 40 \%<\mathrm{CSI} \leq 60 \%=\text { fairly satisfied } \\
& 60 \%<\mathrm{CSI} \leq 80 \%=\text { satisfied } \\
& 80 \%<\mathrm{CSI} \leq 100 \%=\text { very satisfied }
\end{aligned}
$$

\section{RESULT}

\section{Analysis of Satisfaction Level on the Importance and} Performance

The average scores of the level of importance and performance of each bio-farm product's attribute are tabulated into the Cartesian diagram. The calculation of the average scores of the level of the organic liquid nutrition product's importance and performance is presented below.

Table1. The calculation of the average scores of the level of the organic liquid nutrition product's importance and trust

\begin{tabular}{|lllll|}
\hline Variable & total ei & total bi & y & x \\
& & & & \\
Benefit & 224 & 204 & 4.48 & 4.08 \\
Packaging & 203 & 162 & 4.06 & 3.24 \\
Price & 165 & 141 & 3.3 & 2.82 \\
Product's & & & & \\
Information & 221 & 201 & 4.42 & 4.02 \\
Content & 213 & 203 & 4.26 & 4.06 \\
& & & 4.104 & 3.644 \\
\hline
\end{tabular}


After finding out the axis points in the quadrant, $\mathrm{Y}=$ 4.104 and $\mathrm{X}=3.644$, the $(\mathrm{X}, \mathrm{Y})$ of each attribute is put into Cartesian diagram. See Figure 2.

Notes:

Product's Benefit

Product's Packaging

Price

Product's Information Product's Content

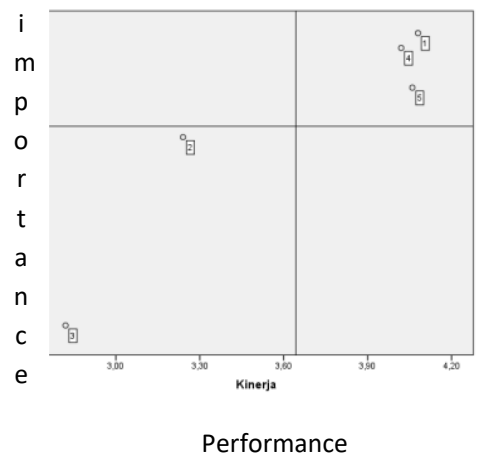

Figure 2. Cartesian Diagram of Bio-farm Product

\section{Quadrant I (High Priority)}

Quadrant 1 has shown high priority or important attributes for the costumers. The condition is far different from the expectation, resulting in the respondents' dissatisfaction on the product. However, the Cartesian diagram does not show any attribute representing the respondents' satisfaction, and thus no attribute is found in this quadrant.

\section{Quadrant II (Maintaining the Achievement)}

This quadrnt has shown that the important attributes for the cstomers are directly proportional to the product's performance, generating the respondents' satisfaction. Those attributes are product's benefit, information, and content.

For he respondents, the product's benefit and performance are crucially important, implying that the company is to maintain those two aspects so as to make the customers satisfied.As for product's information displayed on the packaging or other media such as the product's brochure, the respondents state that it has been properly available. Accordingly, the respondents are satisfied. Product's content is another vital aspect to consider by the respondents, as the benefit of the organic liquid nutrition product is inseparable from its content.

\section{Quadrant III (Low Priority)}

It is illustrated that the attributes of the organic liquid nutrition product belonging to this quadrant are less important; their performances are considered to be less. There are two attributes shown in this quadrant, namely packaging and price.

Packaging attribute is one of attributes less considered by the respondents. Similarly, price attribute is as well. As long as the quality and result of the product are promising, these two attributes (packaging and price) are not the points of consideration for the customers upon choosing the product.

\section{Quadrant IV (Excessive)}

This quadrant is to display the less important attribute with relatively high and satisfying performance. This sort of attribute is not found in the Cartesian diagram.

To support the investigation on the customer satisfaction on the bio-farm product, the CSI has resulted $73.88 \%$. It has shown that the respondents' satisfaction belongs to the scale of $60 \%<\mathrm{CSI} \leq 80 \%$, implying that the respondents are satisfied with the bio-farm product.

Discussion

Kotler and Keller (2008) assert that product is the key determinant among the entire market demands. In addition to that notion, product is defined as the perception of customers described by producers through their production results (Tjiptono, 2008).

Decision making constitutes an activity performed by individuals directly involved in acquiring and utilizing any offered products. Different results have been generated and drawn from product performance and customers' interests, in which the tested variables have been found to locate in two quadrants (II and III) in IPA Cartesian diagram.

First, the results of IPA diagram have revealed that product's benefits, content, and information fall into quadrant II. It denotes that those mentioned variables have become primary needs that are available in the biofarm product. This sort of finding is in line with experts' opinions conveying that product's attributes affect the decision of customers to buy particular products. a. Product Quality (product's benefits and content)

In this regards, Kotler and Armstrong(2008) affirm that product quality is the ability of any product to play its functions, namely: reliability, durability, precision, handy operability and serviceability, as well as some other valuable attributes. It is further underpinned by Vincent Gaspersz(2005 in Alma, 2011) clarifying that the dimensions of product quality are as follows: (1) performance, (2) features, (3) reliability, (4) conformance to specification, (5) durability, and (6) serviceability (speed, competence, comfort, and handy operability). In this case, the functions and dimensions of the bio-farm product quality have been well accepted by the customers, implying that the company is to maintain as well as continuously develop this positive condition.

b. Product Information

Schiffman and Kanuk (2004: 547) state that any decision to purchase certain product derives from a choice between two or more alternatives. It implies that in making a decision, some alternatives/options are to be available. Purchase decision refers to buyer decision making process. This so-called decision is closely tied to customers' decision after considering of either buying or choosing other products by taking into account necessary and real information related to certain product. The provided information is one of contributing factors to any purchase, and thus it is to be maintained by any company/producer.

Second, different from those in quadrant II, quadrant III shows the relatively low customer priority and 
Table 2. The calculation of CSI

\begin{tabular}{lcccc}
\hline \multicolumn{1}{c}{ Variable } & total ei & total bi & y & $\mathbf{x}$ \\
& & & & 4.08 \\
Benefit & 224 & 204 & 4.48 & 3.24 \\
Packaging & 203 & 162 & 4.06 & 2.82 \\
Price & 165 & 141 & 3.3 & 4.02 \\
Product's Information & 221 & 201 & 4.42 & 4.06 \\
Content & 213 & 203 & 4.26 & 3.644 \\
\hline
\end{tabular}

satisfaction. Quadrant III covers up packaging and price. These two variables are located in a quadrant that obliges the company to evaluate further so as to fulfill customer satisfaction, apart from not becoming the main priority of customers.

\section{c. Packaging}

Kotler and Amstrong (2008) define packaging as an activity of designing and producing the cover for packing or wrapping a product. Packaging should be interesting and appealing so as to bring more values to customers, though there are some other products offering similar shape and quality. That is not the case when the packaging is found to be common as those of other products, but customers consider other variables, such as product quality and information.

\section{d. Price}

Price is the amount of money to pay by market. From the marketing point of view, price constitutes monetary unit or measure of product or service that has to be exchanged in order to get proprietorship rights upon the product or service (Kotler and Amstrong, 2008). Tjiptono (2001) explains that price is frequently used as value indicator, that is related to the benefits taken out of particular product or service. The relatively low priority of Price variable, in this case, is caused by the preference of agricultural product customers towards product quality. The relatively low customer satisfaction has been caused by the availability of similar products (with lower quality) that are sold in lower price. The further implication is that it is necessary for the company of biofarm product to introduce and arouse the product knowledge of the targeted customers

\section{CONCLUSION}

This current research has revealed that the customers are satisfied with the Bio-farm product, proven by the customer satisfaction index of $73.88 \%$. It has been shown that price and packaging are less prioritized by the customers; whereas, the product's benefit, information, and content are the key determinants for the customers to chose the Bio-farm product. This research ends up with the implication that those three attributes are what businessmen and companies should pay attention to as well as continuously maintain.

\section{REFERENCES}

[1]. Andrianto, Hendra Noky and Idris. Pengaruh Kualitas Produk, Citra Merek, Harga, dan Promosi Terhadap Keputusan Pembelian Mobil Jenis MPV Merek Toyota Kijang Innova di Semarang. Diponegoro Journal of Management. Vol 2, No 3, pp. 1-10. 2009

[2]. Fandy, Tjiptono. Manajemen Pemasaran dan Analisa Perilaku Konsumen, BPFE, Yogyakarta. 2001

[3]. Fandy, Tjiptono. Strategi Pemasaran. 3rd Ed. Andi, Yogyakarta. 2007

[4]. Gaspersz, Vincent. Total Quality Management. PT Gramedia Pustaka Utama, Jakarta. 2005

[5]. Kotler and Armstrong. Prinsip-prinsip Pemasaran. Jilid 1 dan 2. 12th Ed. Erlangga, Jakarta. 2008

[6]. Kotler, Philip and Armstrong, Gray. Marketing Induction: An Asian Perspective. Prentice-Hall, New Jersey. 2003

[7]. Moorman, Christine, Rohit Deshpande, and Gerald Zaltman. Factors Affecting Trust in Market Research Relationships. Journal of Marketing. Vol 57. pp 81-101. 1993

[8]. Nitisusastro, M. Perilaku Konsumen dalam Perspektif Kewirausahaan. Alfabeta, Bandung. 2011

[9]. Peter, Paul and Olson, Jery C. Consumer Behavior Perilaku Konsumen dan Strategi Pemasaran. $4^{\text {th }}$ Ed.Vol. 1.Penerbit Erlangga, Jakarta. 2014

[10]. Rangkuti, F. Measuring Customer Satisfaction: Teknik Mengukur \& Strategi Meningkatkan Kepuasan Pelanggan \& Analisis Kasus PLN JP. Gramedia Pustaka Utama, Jakarta. 2003

[11]. Schiffman and Kanuk. Perilaku Konsumen. 7th Ed. Prentice Hall, Jakarta. 2004

[12]. Supranto, J. Pengukuran Tingkat Kepuasan Pelanggan untuk Menaikkan Pangsa Pasar.Rineka Cipta, Jakarta. 1997 
[13]. Yola, M and Budianto, D. Analisis Kepuasan Konsumen terhadap Kualitas Pelayanan dan Harga Produk pada Supermarket dengan Menggunakan Metode Importance Performance Analysis (IPA).Jurnal Optimasi Sistem Industri 12(2):301309. 2013 